\title{
A Rare Entity: RACAND Syndrome
}

\author{
Mohamed Elqatni, Fadwa Mekouar, Taoufik Amezyane and Driss Ghafir
}

Key words: anticentromere antibodies, Raynaud's phenomenon, digital necrosis, RACAND syndrome

(Intern Med 53: 2749, 2014)

(DOI: 10.2169/internalmedicine.53.2757)

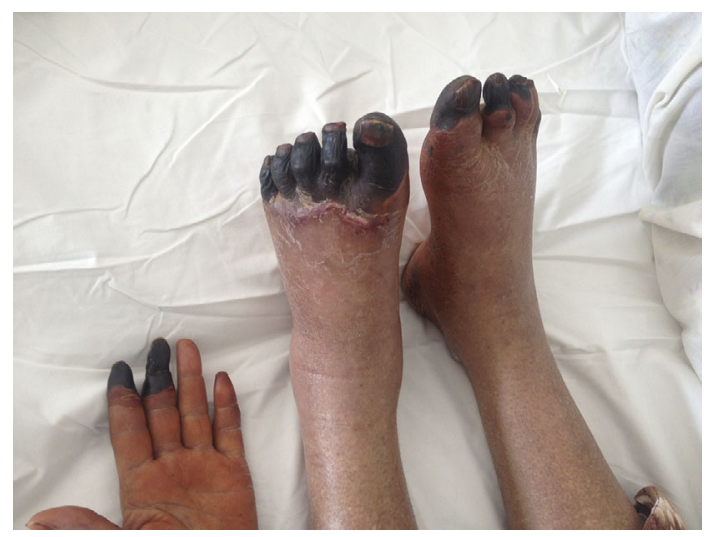

Picture 1.

A 64-year-old woman, a non smoker without diabetes and hypertension, was hospitalized with severe necrotic lesions on the third left finger and inferior side of all toes lasting for one month (Picture 1, 2). She had suffered from Raynaud's phenomenon for the past year. There were no signs of cutaneous sclerosis, telangiectasia or calcinosiscutis. Investigations for pulmonary, esophageal and renal involvement, including pulmonary function tests, chest X-ray, highresolution computed tomography (CT) scans of the lungs, upper gastrointestinal endoscopy and creatinine clearance tests remained negative. Vascular examinations showed no signs of macroangiopathy. Anticentromere antibodies were detected at a titer of 1:10,000. There were no cryoglobulins, antiphospholipid antibodies, anti-neutrophil cytoplasmic antibodies or antibodies against Scl-70, Ro, La, Sm or RNP.

We initiated treatment with prednisone, followed by infusions of anticalcic agents and iloprost at a dose of $2 \mathrm{ng} / \mathrm{kg}$ per minute over five days, without any success, and the ne-

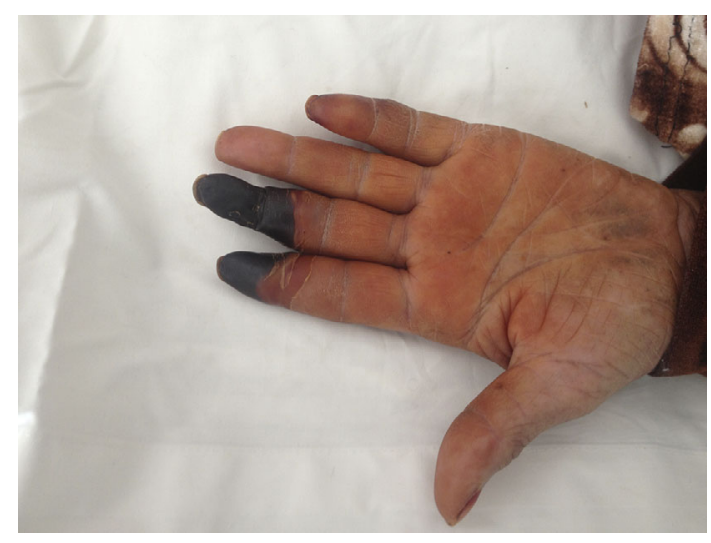

Picture 2.

crotic digits thereafter had to be amputated.

The acronym RACAND refers to the association of Raynaud's phenomenon, anticentromere antibodies and digital necrosis without digital sclerosis. It is a rare syndrome that has recently been individualized. Digital necrosis is usually described at the digital level, but rarely in the toes $(1,2)$.

The authors state that they have no Conflict of Interest (COI).

\section{References}

1. Sachsenberg-Studer EM, Prins C, Saurat JH, Salomon D. Raynaud's phenomenon, anticentromere antibodies, and digital necrosis without sclerodactyly: an entity independent of scleroderma? J Am Acad Dermatol 43: 631-634, 2000.

2. Abouzahir A, Badaoui M, Amezyane T. RACAND syndrome associated with primary biliary cirrhosis. Rev Med Interne 31: e11e13, 2010.

Department of Internal Medicine, Mohammed V Military Teaching Hospital, Mohammed V-Souissi University, Morocco

Received for publication March 3, 2014; Accepted for publication April 29, 2014

Correspondence to Dr. Mohamed Elqatni, elqatni@yahoo.fr

(C) 2014 The Japanese Society of Internal Medicine Journal Website: http://www.naika.or.jp/imonline/index.html 